\title{
The Importance of Leadership and Vision in Born Globals
}

\author{
Ingemar Wictor (Corresponding Auther) \\ School of Business and Engineering \\ Halmstad University \\ Box 823, S-301 18 Halmstad, Sweden \\ Tel: 46-35-167-583 fax: 46-35-133-879 \\ E-mail addresses: ingemar.wictor@hh.se \\ Svante Andersson \\ School of Business and Engineering \\ Halmstad University \\ Box 823, S-301 18 Halmstad, Sweden \\ Tel: 46-35-167-100 fax: 46-35-133-879 \\ E-mail: svante.andersson@hh.se
}

Received: December 9, 2011

Accepted: January 20, 2012 Published: March 1, 2012

doi:10.5430/bmr.v1n1p13

URL: http://dx.doi.org/10.5430/bmr.v1n1p13

\begin{abstract}
Since the beginning of the 1990s studies of Born Global companies has become a major topic in internationalization literature. Earlier research has pointed out the importance of the entrepreneur in the born global firm's international development. Even if many studies have been done which identify the impact of entrepreneurs and management on firms' internationalisation and behaviour few studies have focused on leadership in Born Global Companies. Following earlier research, the aim of this paper is to investigate how the entrepreneur uses his/her vision in Born Global companies. The main findings and conclusions are that the entrepreneur and his/ her vision have an important role in these companies. The vision is like an umbrella and affects many important parts of the company, such as organisation, communication, recruitment, knowledge transfer and other parts that will form the company's culture. The born global entrepreneurs create the company values and motivate the employees in the organisation. The Born Global leaders share the power with subordinates. It is crucial to delegate operational decisions to subordinates so the entrepreneur can work with strategic issues fostering the firms' international expansion. Communication is open and straight with an open atmosphere in the culture. Good communication is important when building goals, values and conveying the leader's vision. Even if the entrepreneurs motivate their employees in a positive way the entrepreneurs still have a tight control of the company. The main implications from this study are that the entrepreneurs in The Born Global firms have been able to create an innovative culture in the firm that creates international growth.
\end{abstract}

Keywords: Entrepreneurs, Born global, Leadership, Vision, Communication, Motivation, Recruiting

\section{Introduction}

During the past few years, the Born Global phenomenon has been highlighted in many studies. Such firms adopt a global approach from their launch or very shortly afterwards. This behaviour challenges the traditional models of internationalisation that propose that internationalisation is developed in a slow and gradual manner with respect to geographical markets and market entry modes. In an earlier paper we found a conceptual framework developed from earlier research, including the following factors: globalisation, entrepreneurs, networks and industry. A survey showed that Born Global companies were still very uncommon in Sweden. However, four Born Global firms were identified and analysed within the framework. It could be concluded that on-going globalisation has made it easier to conduct Born Global strategies. However, active entrepreneurs who saw that global opportunities were crucial to implement these strategies and their personal networks were used as tools (Andersson and Wictor, 2003). Still the speed is important; according to Verdier, Prange, Atamer and Monin (2010, p. 21) "the increased level of globalization in many industries 
may further lessen the perceived risk of entering foreign markets and partly explains the observed increase in the speed of internationalization".

An increasing amount of interest has been shown in the international development of these firms (Andersson, 2000, Nummela et al., 2003). Early internationalisation has been shown to be a successful strategy for some SMEs (Madsen and Servais, 1997). Studies have shown that entrepreneurs can choose to internationalise quickly and become global shortly after their inception (e. g. Rennie, 1993; Knight and Cavusgil, 1996; Madsen and Servais, 1997). In these studies, top management and entrepreneurs are regarded as crucial for the firms' international strategies (Andersson, 2000). For reviews of research of born globals see Rialp et al. (2005); Zahra (2005) or Aspelund et al. (2007), Keupp and Gassman, (2009), Jones et al. (2011).

Much of the literature discussing the Born Global phenomena has been connected with new industries and high-technology-based sectors (Crick and Jones, 2000). However, the phenomenon has, in later research, also been found in other "old" and mature sectors (Evers, 2011), such as the arts and crafts business (McAuley, 1999). Globalisation trends set up more opportunities for firms, but culture, language and market channels differ between different countries and regions. For that, we need acting individuals and firms that chose to see the international opportunities (Andersson, 2000).

Perhaps the most common denominator in Born Global research is the importance of the entrepreneur and entrepreneurial behaviour (Rennie, 1993; Knight and Cavusgil, 1996; Madsen and Servais, 1997; McAuley, 1999; McDougall et al., 1994). However, research on entrepreneurs and entrepreneurship is a very wide area, some focusing on the individual entrepreneurs' characteristics (Gartner, 1989), others on the individual entrepreneurs' personal network (Johannisson, 1994), while others do not focus on the individual person but on firms' entrepreneurial behaviour (Covin and Slevin, 1989; McDougall and Oviatt, 2000). The interest in international entrepreneurship has grown rapidly during the past few years (McDougall and Oviatt, 2000). One of the most frequent definitions of international entrepreneurship is: "international entrepreneurship is a combination of innovative, proactive and risk-seeking behaviour that crosses national borders and is intended to create value in organisations", (McDougall and Oviatt, 2000, p. 903). This definition is heavily influenced by Covin and Slevin (1989), and does not explicitly focus on the individual entrepreneurs within a firm but focuses on the entrepreneurial behaviour on firm level. This paper contends that individuals within a firm, at management level, are the dominant determinant of a firm's pattern of entry into new markets. This is in line with research discussing Born Global companies (Madsen and Servais, 1997) new international ventures (McDougall and Oviatt, 1994) and instant exporters (McAuley, 1999). These studies point out that analysis on an individual level is important to understand firms' international behaviour.

Even if many studies have been done which identify the impact of entrepreneurs and management on firms' internationalisation and behaviour, more studies and research are needed to understand what happens in a Born Global company. The importance of the vision in Born Global companies and how the entrepreneur uses it in the company need to be studied more deeply. This is in line with Rialp et al., (2005) and Andersson and Evangelista (2006), who state that there is a need for more probing case studies to understand the firms' early internationalisation.

For these entrepreneurs, a global strategy is the most natural strategy, while most others should choose another strategy. However, to succeed with a Born Global strategy it is not enough to have an entrepreneur with a global vision. The entrepreneur has to create an organisation which will carry out his vision. The aim of this paper is to investigate how the entrepreneur uses his vision in a Born Global company.

This paper proceeds with a review of the literature. We then present the case methodology following by three case description from Sweden. Empirical case findings are discussed and analyzed to capture how the entrepreneurs are using his vision to lead the Born Global companies followed by a discussion. Conclusions and managerial implications are finally drawn.

\section{Literature Review}

\subsection{The Entrepreneur's Vision}

Spence (2003) has, in her study, pointed out the importance of networks and that few high-tech SMEs followed a planned international strategy. Internationalisation happens in a holistic way. By being part of different networks, entrepreneurs found opportunities which led to international expansions. She points out the importance of the entrepreneurs' vision, which is built upon their own assembled strategies, how the individual looks upon his own environment, about how the organisation should be arranged and how he interprets his surroundings. Also Rialp et al. (2010) point out the importance of the entrepreneurs' vision within the initial stages of a business creation in born global firms. This is in accordance with the Entrepreneurial School (Mintzberg, et al., 1998) and "the strategy formation as a 
visionary process". The vision is represented by the mental process started in the entrepreneur's mind. The vision contains both inspiration and common sense over what to be done and as a common thread as to how to reach the goal. This vision is not written down; it is formed as a mental map. The map can be adjusted in accordance with the entrepreneur's own experiences. His strategy will then give the important guidelines for the organisation, but changes can still be made. The importance of this has also been shown by Nummela et al. (2002) who state that a manager's global mindset is important for international performance. Mental thinking forms an entrepreneur's visions and is a base for selecting different strategies. McDougall et al. (1994) and Madsen and Servais (1997) all concluded that an entrepreneur's background has a large influence on the formation of a Born Global company. According to Spence and Crick (2009) the managers must have broad vision of what they want to reach in the future and to be flexible in their strategies of how to meet this vision.

During the past few decades, leadership discourse has changed from managing through order to a situation where personnel are supposed to take responsibility for their own actions, and that management can be implemented by a vision (Beckérus and Edström, 1988). This means that a leader must be able to influence their employees' understanding of their jobs and their surroundings (Sandberg and Targama, 1998). Beckérus and Edström (1988) argue that the new leadership has a new view of employees, where an individual's personal development is in focus and should be put at the centre of business thinking. Another priority is the company's culture, which is built on participation and affiliation. A central theme is competence mobilisation and developing competence. There will be a demand to solve tasks together with others. A new management role will be to break old structures and to form participation (Beckérus and Edström, 1988). In this new perspective, the people in the organisation are assumed to use their own initiative. This means that each person in the organisation must be more competent and understand their role in the organisation and what tasks they have to solve. For that reason, it is important for the employees to understand the company's strategic target or vision (Sandberg and Targama, 1998).

Sandberg and Targama (1998) also state that it is about an understanding and interpreting perspective. They interpret it as the knowledge we have about reality as a social contraction. Furthermore, this means that our idea of reality is created by ourselves and others based on our own experiences and in communication and cooperation with other people. This will give us a collective view on reality for a whole group.

To implement the entrepreneur's vision in an organisation it is important to create an organisation with a culture in line with his vision. In this process, it is important to have a recruitment strategy in line with the organisation's culture. The employees should have the same values as the founder. The entrepreneurial atmosphere is an important part in the company's culture (Mintzberg, 1989). The founders of new organisations are very often charismatic individuals, and people who join and stay in the new organisation do it because they relate to the leader and his mission (Mintzberg, 1989). The "engaged" staff will also help to strengthen the company's culture (Schwartz, 1997).

\subsection{Leadership and Communication}

Simonsson (2002) argues that management plays an important role in internal communication. Building the company's formal communication channels are just one part in this complex matter. The new view on leadership is kept together through collective goals, values and the entrepreneur's vision. To make it possible to transfer knowledge, the leader must have the competence to build participation and use rhetoric (Simonsson, 2002). Being able to create trust is another important part of good leadership (Misztal, 1998).

Motivation is important when transferring knowledge. Illeris (2001) discusses motivation psychology, where it is important to understand different organic, emotional, social and cognitive motives.

The tacit knowledge and the explicit knowledge, which could be found in other parts of the organisation, can be difficult to transfer to other colleges in the organisation. Japanese companies have created special "talk rooms" to increase the transfer, and another way the Japanese share knowledge is to arrange a group dinner. It is always important to take into consideration the culture of the local country (Davenport and Prusak, 2000).

Explicit knowledge can normally be found in a document or database, and is easy to find. However, the transfer of tacit knowledge is more complicated. The contacts must be more intensive to give a positive result. Davenport and Prusak (2000, p. 95) state that: "tacit knowledge transfer generally requires extensive personal contacts. The 'transfer relationship' may be a partnership, mentorship or an apprenticeship, but some kind of working relationship is usually essential. Such relationships are likely to involve transferring various kinds of knowledge, from explicit to tacit."

In most situations, it is important to trust each other and have some sort of common ground to stand on - this could be the same language or the same values. Language may, in this case, be technical or market adjusted. How the transfer is 
done, how it is absorbed by the receiver and how this person can use it practically must be taken into consideration whether the knowledge has been transferred or not (Davenport and Prusak, 2000).

The conception of "trust" plays an important role as inspiration for cooperation, and to achieve this we must act in a trustworthy way. It is important to know in which context it is used. In modern organisations trust is important in global situations and changes (Misztal, 1998). Misztal defines trust as: "a social mechanism which can be explained by people's beliefs and motivations. To trust is to believe that somebody's intended action will be appropriate from our point of view. Social relations and obligations inherent in them are presented as being mainly responsible for the production of trust. To hold that trust cannot be fully understood without an examination of institutions leads to the argument that the problem of constituting trust in society is an issue concerning the conditions necessary for social order" Misztal, 1998, pp. 9-10).

Sense-making has an important role in Born Global companies. Rasmussen, Madsen and Evangelista (2000) state that it is important if the founder of the company starts from "zero" or if he uses his old experiences from other companies, especially to build up networks, the organisation and the market structure. How can he use his former experiences to build "a mental picture" of the forthcoming organisation and marketing strategy? A new market may, for the founder, be very well known due to his former experiences. Rasmussen, Madsen \& Evangelista (2000) use Weick's (1995) sense-making concept to discuss the founding of the Born Global Company. They especially focus on how the sense-making process always starts with an individual. In a Born Global case, the entrepreneurs who start a Born Global company and how the sense-making is retrospective, that is, how the Born Global entrepreneurs look back on earlier events when they start their new company.

\section{Method}

As the study is exploratory in nature, a case study approach was considered to be the most appropriate (cf. Yin 1994). To collect empirical data, a mix of qualitative methods was used. Face to face and phone interviews were conducted and were retrieved. Firms' institutional websites were also browsed. This triangulate approach was meant to provide different types of information about firms.

We have used theoretical sampling to find cases that suit our aim (Miles and Huberman, 1994). Our main criteria were to find Born Global firms. The following definition, influenced by Knight and Cavusgil (1996) and Oviatt and McDougall (1994), was used: "A Born Global company is a company that has achieved a foreign sales volume of at least $25 \%$ within three years of its inception and that seeks to derive significant competitive advantage from the use of resources and the sales of outputs in multiple countries." From this Born Global definition, we have identified three firms. To preserve confidentiality, the names of the firms have been changed.

The studied companies are: Diagnostic Products, Rubber and Transformer. They are all Born Global companies with important and strong-minded entrepreneurs. The information has been collected over a number of years, with Rubber taking part in three foundation projects during 2001-2008. Different interviews have been carried out with Diagnostic Products and Rubber. Only one interview has been carried out with Transformer.

To achieve a high quality in a study like this, you have to get close to the informant/ entrepreneur. That means that you have to reduce the gap between the informant and yourself to get access to that person. To a certain extent, researchers may reduce the gap between themselves and high-level executives by adopting a business-like or "insider" approach" and also in accordance to Welch et al. (2002, p. 626) "adopt the position that elites should be interviewed when the research question suggests so".

Following Eisenhardt's (1989) recommendations, the analysis of the data included several steps. The information from interviews and other sources were written down in narratives. This process allows the researchers to become intimately familiar with each case and allows the unique patterns of each case to emerge before cross-case comparison (Yin, 2003; Eisenhardt, 1989).

\section{Findings}

\subsection{Diagnostic Products}

\subsubsection{Company Background}

In 1974, the two inventors of the Diagnostic Products system began to develop the cuvette system. Diagnostic Products systems are still based on patented cuvette technology, which is a unique chemistry reagent and analyses instruments. The system that is used does not require mixing reagents, dispensing or pipetting. The instruments that are produced are factory calibrated and the cuvettes are produced without any need for adjustment in batch-to-batch variation. For the laboratory staff, this means a minimum amount of product training and instrument maintenance to be able to perform 
tests with accurate results. According to the CEO of Diagnostic Products, "the two inventors were very visionary people".

The Diagnostic Products' B-Haemoglobin system was introduced in the early 1980s and the Diagnostic Products' B-Glucose system was introduced on a worldwide basis at the beginning of the 1990s. Since its introduction, Diagnostic Products has installed 140,000 instruments globally. Diagnostic Products has few products, but many customers and market segments. Some examples are blood banks, intensive care departments in hospitals, diabetes clinics and testing centres for haemoglobin, glucose or both. From the company's inception, Diagnostic Products saw the whole world as its market, but the US market was especially important. The company had no money for an intensive international market expansion. In 1986, another big company in the south of Sweden acquired Diagnostic Products. This was a much bigger company and it was not interested in developing Diagnostic Products. In 1994, it was sold through a MBO (Management buyout) to the staff of Diagnostic Products.

Diagnostic Products prefers to use a combination of independent distributors and franchising when it enters new markets. The US market is very important and Diagnostic Products has a subsidiary which handles the distribution/logistic organisation. Due to the fact that the product is a niche product, the market must be a global one. The company has a very strong global business concept, but it is still working one step at a time when entering new markets. The US market is very important for Diagnostic Products. It is a question of "to be or not be". "For our company, being on the US market is a question of survival" (CEO, Diagnostic Products).

The way Diagnostic Products entered the US market is very interesting. The entrepreneur, the CEO, who was responsible for the US market at that time, used a researcher to moulder of public opinion to break a new way for information. This was done in combination with a generous offer to the independent distributors - a $100 \%$ margin. The CEO pointed out: "we entered the US market without spending a single Swedish crown, but it was a bad idea to later lower this very good margin."

In connection with starting up the internationalisation process in the important US market, a new CEO was employed. $\mathrm{He}$ was an entrepreneur with previous experience in a number of different companies in the industry. He can be characterised by his own statement: "Actions speak louder than words!" He means that, especially in fast-growing companies, the focus on organisation and leadership is important. Still, the team is the most important part of the organisation. Local and international networks were important for Diagnostic Products' early development, especially when entering the US market, and the CEO used former contacts from previous jobs.

Diagnostic Products has a professional Board. Over time, the members have played a central role, especially during the early internationalisation period.

\subsubsection{The Entrepreneur's Vision}

The entrepreneur needs a strong organisation, so he can expand the market under control He works a lot throughout his vision. His target for the organisation is to have the right person in the right position. This way of working has been in place since the entrepreneur who started the new internationalisation period, in 1990, has been in a position to develop the organisation. He has gained his experience from different companies and was the builder of the new market in the USA. The entrepreneur has a qualification in international marketing from Lund University. The expansion of the company has given him the opportunity to make very important changes to the organisation during this period.

The people recruited during his leadership period have been hand-picked to be able to develop in an international surrounding. It is important that they have had the experience of living abroad, have a good knowledge of languages and understand that export and internalisation are important parts of the business. This is where the company makes its living, and other important aspects are to find distributors and to know how to act in the market. The employees are expected to be well educated with a lot of experience and to bring "new blood" into the organisation. The level of their language level is always controlled and the company has built a steeplechase to make sure that the right person is employed.

\subsubsection{Leadership and Communication}

The entrepreneur states that "leadership is everything" and that an open atmosphere is the main requirement for good communication. For him, central conceptions are the vision, courage to act and a good leadership culture. In his leadership style he uses the following three targets: focus-vision, products and geographical markets. When interviewing individuals he gives them a "handbook" which describes the company's culture.

It is also important to create an atmosphere that encourages people to be open-minded, so that knowledge can be reached by all the people in the organisation. The entrepreneur has no special strategy for transferring knowledge. He means that 
"he, as a person, is pragmatic - he lives as he teaches" (CEO, Diagnostic Products). He likes clear goals, and believes that it is important to be personally present in the company. The company's common value system is an important feature, where correct rules for how to work ethically, morally and in forming relationships with customers and the market are defined so that all people in the organisation know what is right and what is wrong. To understand how the people should act in relation to each other, he states: "The culture in the company is important when you recruit new people; they are the ones who shall bring what is developed further" (CEO, Diagnostic Products). The entrepreneur states that the individuals in his organisation are very interested to find knowledge and are very interested in learning. $\mathrm{He}$ also states that the company should be seen as the very best on the local market. The people in the organisation are highly motivated and work in a dynamic situation. The level of education of the staff within the company is very high, and it includes many academics. The company believes further education is very important and it continually invests in education. The entrepreneur sees good leadership as vital to the business: "do not hesitate to move an employee - have a good recruiting process, be honest, inform people about your business ethics and what your morals are, talk about the company's culture - develop discussions, show your leadership skills - show yourself often, write down your company's culture, focus on the fact that the employees have fun - do things and live as you learn" (CEO, Diagnostic Products).

The entrepreneur is very much "a hands-off leader". He likes people who like to drive their own race but have good communication skills. In the company there is a strong combination of knowledge and experience. "You have to find those people who are the ones who are going to play in the best league tomorrow. Make sure that you recruit the people with the right abilities and do not be afraid of competence" (CEO, Diagnostic Products).

The establishment of the company has been driven by the entrepreneur, executives and managers using a combination of high levels of education and experience. To establish the new concept in the USA is a good example of this. For the market in Germany, the US concept was also used. This means that a pre-organisation model was implemented. The experiences gained from USA could also make sense in Germany.

\subsection{Rubber}

\subsubsection{Company Background}

Rubber was founded by four colleagues from a company where they were employed in different positions. The four colleagues who previously worked together, in different positions, in the same company, saw more opportunities than the owner and therefore started their own business, Rubber, in 1990. Rubber's business is based on a multi-diameter technology, protected by patent. Rubber's products consist of a system of cable entries and seals, based on the multi-diameter technology. Besides this, it also offers custom-made systems. From its inception, Rubber saw the whole world as its market. It has entered approximately 10 markets per year and it has a presence in more than 80 nations. The main strategy in its early expansion was to work via independent distributors. This was an outspoken strategy to be able to enter many markets with small resources. In the past few years it has also established seven subsidiaries. These subsidiaries are sometimes regional offices, like the one in Madrid which is also serving Latin America, and the one in Dubai which is serving the Middle East.

The export share is at least $85 \%$ of the turnover. From the beginning, Rubber's vision was to work with independent distributors, but that does not always function well. In the important US market it did not work, so it had to improve its interest in the company. Today, it has increased the number of subsidiaries it has.

Cables and pipes are everywhere. When they are routed through openings from one area to another, no fire, gas or water is generally allowed to penetrate; neither is dust, dirt, insects, rodents or snakes. Some installations have further to withstand corrosions, pressure differences, vibrations and electromagnetic radiation. This is a target for Rubber to be a world leader (www.rubber.com).

Rubber prefers to use Swedish immigrants when it is entering new markets. There are no competitors due to the type of product it is working with. The product is too complex to produce. For example, if Rubber was interested in the Chilean market, it would try to find a Chilean person who wants to return to Chile. Rubber would then educate the person in Sweden and the individual and their family would return to Chile to start a business as an independent distributor as a partner to Rubber. Local partners may also be independent distributors in other countries.

For Rubber, the global business concept is very important, but the local organisation in the south of Sweden is processing, analysing and producing all of the market body information. The main way of establishing the market is through independent distributors, and if this solution does not work in the market, the company will start a market subsidiary. But as soon as there is a solution that works, a new independent distributor is asked to take over. As no competitors have a similar product, the company can decide when it will enter into a new market. 
The entrepreneur was one of the founders and Rubber's main owner and chief executive. He had previous experience of international business from his former work in a company in the same industry. When the company grew bigger, in 2000, the entrepreneur recruited a new CEO with experience from large growing companies. The new CEO has experience from large international companies and has lived abroad. He has management experience in large organisations, which has become crucial in the growing organisation. The entrepreneur's local and international networks were important for Rubber's early development. In the early years it was important to have a good position in the local network, especially with local banks, to finance the first few years. An international network was also important to enable Rubber to grow internationally. The new CEO's international network has been useful for Rubber's further international expansion, but at the end of 2002 the new CEO left Rubber.

Today, the company has a new CEO and it is working more with subsidiaries instead of distributers.

\subsubsection{The Entrepreneur's Vision}

The entrepreneur's vision was to be international from the beginning. The internal values the company created in 1994 are central to the company. As a base for these values, he states that: "it is better to own a market than a factory"(Founder). From the start, the business concept has been to: "develop, produce and market multi-diameter-based cables and pipes, which should fit sharply marked off constructions, offering protection against fire, gas, water and electromagnetic disturbance. The world is our market" (www.rubber.com).

The entrepreneur has previous experience of the industry. He worked for a company in the south of Sweden for more than 12 years. He worked with market issues and, at the same time as the executive, he was highly motivated to start this new company together with his sister. His parents have been his model (best practice) for how to work. Because he had a lot of previous experience in the same industry, this has helped him to build the new company. The later CEO (2007), states that: "it is important to have a visionary leadership when we talk about where we want to go, how we are going to reach our goals, to work with 'pep talk', and we should send the same message to all customers, in any country in the world, in accordance with our core values".

Strategic recruiting is used for higher positions in the organisation and through personal networks. Personal qualifications are the most important ones. Recruitment goals are: young and enthusiastic people, completed with people fully experienced and that people will be employed who have better competence compared with entrepreneur. Teamwork is the main way of working in the organisation. Recruiting qualified people, like the R\&D department manager with a doctoral qualification, means that "you raise the holistic approach through this type of recruitment" (CEO, 2007).

The employee must have "the right mindset" to succeed. You can discover a lot of knowledge in the company, but it is not easy to change a person. It is important to have the right person in the business.

\subsubsection{Leadership and Communication}

The entrepreneur is a strong person who needs other strong people at his side. Communication within the company is open: you share your own experiences with others and discuss them together. The entrepreneur's own leadership is important. He must be active and be a hard-working person and be a good member of the organisation. To encourage the organisation is important.

Motivation is important. "If you belong to the management team and operate the organisation with elaborative control there will be no development." It is important to postpone the company's life-cycle curve and the company's goals so that the organisation has the opportunity to be triggered. This creates new possibilities for the organisation. He also focuses on trust: "if you can trust the individuals, you can mentally delegate to your colleagues and, with even more trust, you can develop less friction in the business. In this way, the changes will go smoother and influence the company's development" (CEO, 2007). The employees work as a team and will not be divided in different levels. Division creates barriers and an inefficient organisation, so it is important to be competent and make appropriate decisions. For the entrepreneur to learn is to be well informed about the market situation and to control the competition - this means to always be ahead of them. The employees work in teams which means that different people in the organisation meet in different groups where tacit and explicit knowledge can be exchanged. The culture is open and positive and is open for trial - error situation. Open communication, sharing experiences and discussions are ways to transfer tacit and explicit knowledge. "Information and how it is communicated is continuous and covers the same themes over time" (CEO, 2007).

The entrepreneur has an important role, and his knowledge from his former position is important. He knows the industry. This means that he uses all of his experiences from his former job. Without his former experiences he would not been 
able to start this strongly globalised company. Different networks can be used during the expansion time to form new knowledge, both tacit and explicit.

\subsection{Transformer}

\subsubsection{Company Background}

The idea was to construct a pen which could be used for text transformation based on advanced graphics processing, a digital camera and a quick processing technique. In 1996, a patent application was processed by the Swedish authorities. During 1997, this pen was produced in a laboratory. In 1998, the first pocket version of the pen was tested and negotiations were started with perspective partners. In 1999, the pen was ready for the international market. In same year, the company also started to set up a global standard for paper-based digital communication. During the same period, a subsidiary introduced the intelligent camera supervise system. The target was to become one of the leading companies in this area. As with many other companies, Transformer had to start selling and marketing the product before big companies, such Ericsson and Nokia, were interested in any negotiations.

During the following years cooperation process to engage partners within the mobile telephone, telecom and the paper and pen industry and negotiations started. New generations were introduced. In 2002, Sony Ericsson, together with Vodafone Sweden, introduced the first digital pen "Chatpen" and with Logitech the other digital pen. Nokia started to sell a third pen and other big companies came after. These companies cooperated together through an agreement, which included that they are also producing the pen. Today, Transformer co-operates with big companies all over the world. The main way of working throughout the global world is through licence and partner agreements.

During 2002-2003, the production and marketing concept was changed from Transformer producing and marketing the product on its own to a form of "outsourcing concept", where agreements were signed by big companies such as Ericsson, Nokia and Microsoft. Since this time, the entrepreneur left the position of CEO to become the chairman of the board, but he has now left the company.

\subsubsection{The Entrepreneur's Vision}

During the 1990s, the entrepreneur planned to finish a medical doctor's degree in Neurophysiology at Lund University, but he changed his mind and in the end and took a Master of Science degree in Bioengineering at San Diego. The entrepreneur had a broad academic education and his father was a medical doctor, who had also been researching, was an associate professor and the same background had his grandfather. The entrepreneur's mother was a teacher at an upper secondary school. Just like his father and his grandfather, the entrepreneur started medical doctoral studies and has learned to work with strategies, how the value chain can be divided and how to make money in the long run. The entrepreneur is convinced that this is now part of his personality. This means that the entrepreneur has no previous experience working for another company.

The entrepreneur's vision was to develop a world where people have access to intuitive tools. For digital communication based on the most used and oldest information technology - paper and pen - adapted in accordance with the human beings' natural pattern of behaviour. The mission was to develop a strong technology platform, through a combination of human intelligence and advanced graphics processes, which the company commercialise in a partnership concerning products, services and licences which, for many user groups, connect paper and pen with the digital world.

From the beginning, the entrepreneur had a vision to find the "smartest technicians and those who were most aware of strategic thinking". He was looking for individuals with a Master of Engineering degree and others with a Master of Business Administration degree, in combination with international background, such as growing up abroad or having multicultural parents with the right mental attitude to work with foreign cultures. Recruiting was a strategic situation which sometimes took the entrepreneur a lot of time. His vision was to organise the organisation in accordance with how the customer would expect it to look like at the end. The company was therefore organised into business units (BU). It started with three BUs. The entrepreneur recruited over-qualified people for these positions. He says: "I have not been afraid to use people with strong views. On the contrary, I have always chosen over-qualified people, if I have had the opportunity to choose them" (CEO, Transformer). Today, Transformer has a classic organisation with a person responsible for sales and marketing, technology, patents and legal questions, as well as a CFO. The entrepreneur had a good vision of how to organise the company.

The entrepreneur stated that he had a very exacting organisation from start, and only very competent people were hired. The executives for the three BUs had high positions in their previous companies. The new executives had extensive international experience and knowledge of the English language. The entrepreneur likes strong people with a strong personality. If possible, he always looked for other executives. The entrepreneur does not like people who always say yes. From the beginning he had three executives - this meant that there was a competitive situation in the company. The 
entrepreneur states that some people had potential while others did not. The technician responsible for the technical development was hired from Ericsson.

\subsubsection{Leadership and Communication}

The entrepreneur states that he is a strong and dominate person. Therefore, he wants to employ well-educated, well-skilled and competent people. He likes straight talking and the executives at Transformer are strong and over-competent people. The atmosphere within the company is open-minded and he likes to have strong people in his organisation.

When you employ strong, well-educated people with lots of experience, you will create a special atmosphere. These people, together with the entrepreneur, form a small group which will motivate and transfer both tacit and explicit knowledge between the people in this group. They will then transfer knowledge to their units. In the company they work with different projects. The fact that each person is well educated, highly skilled and works in an open-related atmosphere means that it will be easier to transfer and communicate knowledge to other colleagues and for them to send knowledge, both tacit and explicit, to the executive and other colleagues. Transformer's entrepreneur does not yet work with further education/ training in the organisation. To be able to motivate the employees he has tried different reward systems, including using an individual option programme. He states that the tasks in the company are so professional and learning, so no further education is needed. The employees are also are highly motivated.

All people employed at the company are well educated, highly skilled and have lots of experience. The executives use their previous experience building the organisation and relations to customers and partners. To control a complex situation of relations and the internationalisation process there is a need to use the experience related knowledge in a situation where the amount of money in the short run is a scarce resource and the time for the establishment of the company is limited. The virtual model how to build the company is really important. Too many situations make it impossible to use "the book" as an instruction.

\section{Analysis}

\subsection{The Entrepreneur's Vision}

For the different entrepreneurs, their background has been very important for creating their vision for the companies and managing them successfully. This is in line with what McDougall et al. (1994) and Madsen and Servais (1997) found in their studies. The importance of the entrepreneurs and their entrepreneurial behaviour has been showed in research by, for example, Madsen and Servais (1997) and McDougall et al. (1994). They have a good level of education or previous experience from their former jobs, or a combination of both. Their international experiences are also important. As an example, Rubber's entrepreneur has a lot of international experience but no academic qualifications. Another example is Transformer, where the entrepreneur has previous experience from the academic world and an overseas education, but no international work experience. In Diagnostic Products, the entrepreneur has both an academic education and international work experience.

Their visions show an ability to "think new". This is in line with Nummela et al. (2002) and her view on the importance of the manager's mindset for an international performance. According to Spence (2003), high-tech SMEs follow a planned international strategy. She focuses on the importance of the entrepreneur's vision for how the organisation should be organised to interpret the environment. Also, Mintzberg et al. (1998) focus "the strategy formation as a visionary process". The vision is represented by a mental process which is started in the entrepreneur's mind and includes both inspiration and common sense about what has to be done and how to reach the goals and a map. This map can be changed in accordance with the entrepreneur's own experiences. The entrepreneurs in these studies have constructed new business concepts and mind map fitting new markets and have found new solutions of finding new ways to use a different research method as a moulder of public opinion to pave a new way for information. Another situation is how to build new distributers with immigrants going back to their countries of origin. In the Diagnostic Products' case, "the two inventors were visionary people" (CEO, Diagnostics) and were followed by entrepreneurs with clear visions. According to Sandberg and Targama (1998), the leader must be able to influence the employees' understanding of their jobs and their environment. Spence and Crick (2009) found that managers must have a broad vision of what they want to reach in the future and to be flexible in their strategies of how to meet this vision.

In Rubber, the vision is very important and it has a handbook concerning how to do things according to the way Rubber's rules, which is building on the vision from start. "It is important, with a visionary leadership, when we talk about where we want to go, how we are to reach the goals, to work with 'pep talk', and you should send the same message to customer in any country in the world in accordance with our core values" (CEO, 2007). When you are implementing the vision in an organisation, you need to create a culture in line with the vision. The employees need to 
have the same values as the entrepreneur and the entrepreneurial atmosphere is an important part of the company's culture (Mintzberg, 1989). He states that founders of new organisations are often charismatic individuals. Employees who join the organisation do it because they can relate to the entrepreneur's mission (Mintzberg, 1989).

\subsection{Leadership and Communication}

How you manage to communicate your vision and succeed is dependent on your leadership skills and how you motivate your staff. Simonsson (2002) claims that management staff in the companies play an important role in the internal communication process. To create trust in the organisation is another important part of good leadership (Misztral, 1998). The CEO in Diagnostic Products states that his leadership is characterised by "actions speak louder than words", and he works through his vision. He also states that it is important to be present in the organisation. In the three case studies, leadership has been an important tool for managing the companies' employees. The entrepreneurs act with action and are not afraid to recruit strong individuals or to sack them if they do not fit in with the organisation according to the original informal agreement. Rubber works from the point of view that: "if you have trust for the individuals, you can mentally delegate to your colleagues and develop even more trust. You develop less friction in the business; nonetheless, the changes will go smoother and influence the company's development" (CEO, 2007).

The atmosphere is open and the individuals meet on different arenas and in teams, where the people are motivated. The entrepreneur who makes a lot of sense has to be a role model who can communicate the vision, goals and culture to transfer new, tacit and explicit knowledge, and ways of doing things, giving possibilities to do things wrong and still get a new possibility for new tasks. According to Rasmussen et al. (2000) sense-making has an import role in Born Global companies. Motivating the employees is important, and it is also important for them to have a lot of: "information and how it is communicated is very continuous and concerns the same themes over the time" (CEO, 2007). In many situations, it is important to trust each other and share some sort of common ground to act from, this can be the same language or values (Davenport and Prusak, 2000). Misztal (1998, p. 9-10) defines trust as: "a social mechanism which can be explained by people's beliefs and motivations".

From the beginning, the organisation is already focused on the future challenges of the organisation. The entrepreneurs work with strategic recruiting to find the individuals who fit into the organisation that can also expand the needs of the individuals and develop their potential in an international organisation. The employees should have the driving force in a changing environment to act in the expanding companies. Rubber has recruited very highly qualified managers and it believes that "you raise the holistic approach through this type of recruitment" (CEO, 2007). In Transformer, the CEO states that: "I am not afraid of people with strong views, on the contrary I have always chosen strong people if I have had the opportunity to choose them". According to Nummela et al. (2002) the manager's global mindset is important for international performance and that mindset helps to shape the entrepreneurs' vision, which then is a base for how to select different strategies, such as a strategy for recruiting.

Due to high expectations, Born Global companies normally need a strong educational background and knowledge and experience from previous jobs. According to the CEO of Diagnostic Products, "the company's culture is important and when you recruit new people it is important to recruit the ones that will help to develop the company further" and "you have to find those who are the ones going to play in best league tomorrow and make sure that you recruit the people with the right competence - do not be afraid of competence" (CEO, Diagnostic Products).

Still, the entrepreneur is the person who is responsible for controlling the organisation, even if he cannot control every detail, but he still has overall control. When he is away from the office the staff must trained to be able to make their own decisions.

\section{Conclusions}

The aim of this paper is to investigate how the entrepreneur is using his vision in Born Global companies.

In the cases discussed, we have showed how the entrepreneurs have very clear visions and goals. Earlier research on entrepreneurial strategy (e. g. Mintzberg et al., 1998) is useful to interpret the strategy of the Born Global Company. The entrepreneurs use their vision to control the organisation but also to "think new". An entrepreneur can use explicit guidelines, but it is more important to create a culture in the firm that enables it to create a global organisation.

Recruitment is a very important tool in creating a Born Global company, and so is the entrepreneur's global mindset (Numella et al., 2002) and the entrepreneur's background and experiences from former jobs (McDougall et al., 1994; Madsen and Servais, 1997). The entrepreneurs are aware of the fact that they need competent staff to succeed. In the past, the recruitment processes in Swedish companies has been very traditional: leaders look for people that have a similar background to themselves, they look for staff with similar levels of education, the same sex (males) and the same ethnic background. Born Global entrepreneurs look for characteristics and competencies that complement their own 
knowledge. If they have a good knowledge of marketing, they know that they need someone with expertise in technology. To succeed in the international arena they look for staff with knowledge of the markets they want to enter. The entrepreneur does not only see recruitment as important, he is also very decisive when it comes to dismissing people who he feels does not fit in with the organisation.

A Born Global company is a fast-growing organisation which is present in many different environments. The organisation needs to be organic to be able to fit with the different environments and the growth ambitions of the company. The entrepreneur cannot control in detail what the staffs is doing. He needs staff that can act on their own initiative and do not need detailed instructions. It is also important that knowledge and information is transferred throughout the organisation. A way to transfer and communicate tacit knowledge is to arrange for people to meet and discuss openly in the organisation. Rubber, for example, has no private offices; the CEO/founder has his desk in the corner of an open-plan office. Informal contacts and fast decision-making are encouraged.

The starting point of the organisation, for many Born Global companies, is central to the company's strategy. You have the entrepreneur and 2-3 strategically recruited managers at the top level of knowledge (start of the organisation), when they meet the first time they will open their knowledge "bag" of tacit and explicit knowledge to be used for the expansion of the company. The company's culture will be created by this initial small group of people. The main implications from this study are that the entrepreneurs in The Born Global firms have been able to create an innovative culture in the firm that creates international growth

Further research is encouraged in this area. This study is built on interviews of the entrepreneurs/founders of the company. It would also be interesting to interview the staff in the firms and to get their view of what has happened in the organisation. Another interesting object to study the phenomenon of Born Global companies would be to directly observe the processes in place within a Born Global company.

\section{Managerial Implications}

Managers can learn from this study in different ways: First recruitment is an important activity for building the born global organization. This activity, the entrepreneurs/top management should be directly involved in to secure that the right people are hired. To create a fast-growing international company it is important to recruit people who share the entrepreneur's vison and can work independently. Second, it is important to create an innovative decentralised organization and culture that promotes employees to proactively take decisions and work in line with the entrepreneur's international vision. Here the entrepreneur's actions are important as a role model for the staff. It is crucial to delegate operational decisions to subordinates so the entrepreneur can work with strategic issues fostering the firm's international expansion.

\section{Acknowledgements}

The authors would like to thank The Knowledge Foundation and Halmstad University for financial support.

\section{References}

Andersson, S. (2000). Internationalization of the Firm from an Entrepreneurial Perspective. International Studies of Management and Organization, 30 (1) 63-92.

Andersson, S. \& Evangelista, F. (2006). The entrepreneur in the Born Global firm in Australia and Sweden. Journal of Small Business and Enterprise Development, 13(4), 642-659. http://dx.doi.org/10.1108/14626000610705796

Andersson, S. \& Wictor, I. (2003). Innovative internationalisation in new firms - Born Globals - the Swedish case. Journal of International Entrepreneurship 1, 249-276. http://dx.doi.org/10.1023/A:1024110806241

Beckérus, Å. \& Edström, A. (1988). Tesen om doktinskiftet. In Beckérus, Edström, Å., Edlund, C., Ekvall, A., Forslin, J., Rendahl, Doktrinskiftet-Nya ideal i svenskt ledarskap (pp.11-35). Borås: Centraltryckeriet.

Covin, J. G. \& Slevin, D. (1989). Strategic Management of small firms in hostile and benign environments. Strategic Management Journal, 43, 75-87. http://dx.doi.org/10.1002/smj.4250100107

Crick, D. \& Jones M. V. (2000). Small High-Technology Firms and International High-Technology Markets. Journal of International Marketing, 8(2) 63-85. http://dx.doi.org/10.1509/jimk.8.2.63.19623

Davenport, T. H. \& Prusak, L. (2000). Working Knowledge - How organizations manage what they know. Boston: Harvard Business School Press.

Eisenhardt, K.M. (1989). Building theories from case study research. Academy of Management Review,8(2),. 532-50. 
Evers, N. (2011). 'International new ventures in low-tech sectors - a dynamic capabilities perspective', Journal of Small Business \& Enterprise Development. 18, (3) 502-528.

Gartner, W. B. (1989). "Who is an entrepreneur?" is the wrong question. American Journal of Small Business, 12(4), $11-32$.

Illeris, K. (2001). Lärande i mötet mellan Piaget, Freud och Marx. Lund: Studentlitteratur.

Johannisson, B. (1994). Personliga nätverk som kraftkälla i företagandet. In Johannisson, B. and Lindmark, L., Företag företagare företagsamhet, pp.122-150, , Lund: Studentlitteratur.

Jones, M.V., Coviello, N. Tang, Y. K. (2011) International Entrepreneurship research (1989-2009): A domain ontology and thematic analysis, Journal of Business Venturing. 26 (6), 632-659.

Keupp, M.M., \& O. Gassman. (2009). The Past and the Future of International Entrepreneurship: A Review and Suggestions for Developing the Field. Journal of Management, 35, 3, 600-633. http://dx.doi.org/10.1177/0149206308330558

Knight, G. A. \& Cavusgil, S. T. (1996). The Born Global Firm: A challenge to traditional internationalization theory. Advances in International Marketing, 8, 11-26.

Madsen, T. K. \& Servais, P. (1997). The Internationalization of Born Globals: an Evolutionary Process? International Business Review, 6, 561-583. http://dx.doi.org/10.1016/S0969-5931(97)00032-2

McAuley, A. (1999). Entrepreneurial Instant Exporters in the Scottish Arts and Crafts Sector. Journal of International Marketing, 7(4), 67-82.

McDougall, P. P., Shane, S. \& Oviatt, B. M. (1994). Explaining the formation of international new ventures. Journal of Business Venturing, 9, 469-487. http://dx.doi.org/10.1016/0883-9026(94)90017-5

McDougall, P. P. \& Oviatt, B. M. (2000). International Entrepreneurship: The Intersection of Two Research Paths. Academy of Management Journal, 43(5), 902-906. http://dx.doi.org/10.2307/1556418

Miles, M.B. \& Huberman, A.M. (1994) Qualitative Data Analysis: An Expanded Sourcebook, 2nd ed., Sage, London and Thousand Oaks, California.

Mintzberg, H. (1989). Mintzberg on management: inside our strange world of organizations. New York: The Free Press.

Minzberg, H., Ahlstrand, B. \& Lampel, J. (1998). Strategy Safari: A Guided Tour Through the Wilds of Strategic Management. New York: Free Press.

Misztal, B. (1998). Trust in Modern Societies - The Search for the Bases of Social Order. Malden, USA: Blackwell Publishers Inc.

Nummela, N. (2003). Decision-making in SME Internationalisation: Exploring a Beaten Track? Presented at The Sixth Conference on International Entrepreneurship Research, Derry, Nordirland.

Nummela, N., Saarenketo, S. \& Puumalainen, K. (2002). Global Mindset - A Prerequisite for successful internationalisation? Paper published in the proceedings of the $5^{\text {th }}$ McGill conference on International Entrepreneurship, Montreal, Canada, September.

Oviatt, B. M.\& McDougall, P. P. (1994). Toward a theory of international new ventures. Journal of International Business Studies, 24 (First quarter), 45-64. http://dx.doi.org/10.1057/palgrave.jibs.8490193

Rasmussen, E., Madsen, T. K. \& Evangelista, F. (2000). The founding of the Born Global Company in Denmark and Australia: Sensemaking and networking. University of Southern Denmark, Working Papers in Marketing, No. 25.

Rennie, M. W. (1993). Born Global. McKinsey Quarterly, 4, 45-52.

Rialp-Criado, A, Galván-Sánchez I. \& Suárez-Ortega, S. M. (2010). A configuration-holistic approach to born-global firms' strategy formation process. European Management Journal, 28(2), 108-123. http://dx.doi.org/10.1016/j.emj.2009.05.001

Rialp, A., Rialp, J. \& Knight, G. A. (2005). The phenomenon of early internalizing firms: what do we know after a decade (1993-2003) of scientific inquiry? International Business Review, 14, 147-166. http://dx.doi.org/10.1016/j.ibusrev.2004.04.006

Sandberg \& Targama. (1998). Ledning och förståelse - Ett kompetensperspektiv på organisationer. Lund: Studentlitteratur. 
Schwartz, B. (1997). Det miljöanpassade företaget. Stockholm: Nerenius and Santérus.

Simonsson, C. (2002). Den kommunikativa utmaningen - En studie av kommunikationen mellan chef och medarbetare $i$ en modern organisation. Lund: Sociologiska institutionen, Lunds universitet.

Spence, M. (2003). International Strategy Formation in Small Canadian High-Technology Companies-A Case Study Approach. Journal of International Entrepreneurship 1, 277-296. Kluwer Academic Publishers. Netherlands. http://dx.doi.org/10.1023/A:1024162823079

Spence, M \& Crick, D. (2009). An exploratory study of Canadian international new venture firms' development in overseas markets. Qualitative Market Research: An International Journal, 12(2), 208-233. http://dx.doi.org/10.1108/13522750910948798

Verdier, S., Prange, C., Atamer, T. \& Monin P. (2010). Internationalization performance revisited: the impact of age and speed on sales growth. Management International, Vol. 15, No. 1, pp. 19-31.

Weick, K. E. (1995). Sensemaking in Organizations. Thousand Oaks, CA: Sage.

Welch, C., Marschan-Piekkari, R., Penttinen, H. \& Tahvanainen, M. (2002). "Corporate elites as informants in qualitative international business research", International Business Review, 11, 611-628. http://dx.doi.org/10.1016/S0969-5931(02)00039-2

Yin, R. K. (2003). Case Study Research - Design and Methods. Newbury Park: Sage.

Zahra, S. A. (2005). A theory of international new ventures: A decade of research. Journal of International Business Studies, 36(1), 20-28. http://dx.doi.org/10.1057/palgrave.jibs.8400118 